\title{
Antimicrobial Activity of Seed Extracts from Albizia bernieri E. Fourn. (Fabaceae)
}

\author{
Lovarintsoa Judicael Randriamampianina ${ }^{1}$, \\ Vahinalahaja Eliane Razafintsalama ${ }^{2}$, Danielle Aurore Doll Rakoto ${ }^{1}$, \\ Hanitra Ranjana Randrianarivo ${ }^{1}$, \\ Victor Louis Jeannoda ${ }^{1}$ \\ ${ }^{1}$ Laboratory of Applied Biochemistry to Medical Sciences, Fundamental and Applied Biochemistry \\ Department, Faculty of Sciences, University of Antananarivo, P.O. Box 906, Antananarivo 101, Madagascar \\ ${ }^{2}$ National Center for Application of Pharmaceutical Research (CNARP), P.O. Box 702, Antananarivo 101, \\ Madagascar
}

\begin{abstract}
This work aimed at assessing the antimicrobial activity of Albizia bernieri seed extracts. Methanol extract (SME), alkaloids extracted under basic (Alk1) and acidic (Alk2) conditions, polar saponosides (Sap1) and less polar saponosides (Sap2) obtained by $n$-butanol fractionation were used. Their activities were tested against 9 pathogenic germs including 4 Gram (+) bacteria, 5 Gram (-) bacteria and 1 yeast using disc diffusion and microdilution methods. Regardless the method used to assess the antimicrobial activity, all extracts were efficient but their effects depended upon the germs tested. They all displayed a broad spectrum activity. Alkaloids were by far the most efficient with an excellent effect (Minimum Inhibitory Concentration or MIC $<100 \mu \mathrm{g} / \mathrm{ml}$ ) against all germs tested. Streptococcus pneumoniae, Streptococcus pyogenes, Clostridium perfringens and Candida albicans were the most sensitive with MICs less than $10 \mu \mathrm{g} / \mathrm{ml}$. SME and Sap 2 had moderate or low effects (MIC between 100 and $1000 \mu \mathrm{g} / \mathrm{ml}$ ) and Sapl was the less efficient (MIC $\geq 1000 \mu \mathrm{g} / \mathrm{ml}$ ). All the extracts exerted bactericidal or fungicidal action on all sensitive germs. These preliminary results revealed antimicrobial activity of Albizia bernieri seeds that could be used to treat different infectious diseases and might lead to the development of pharmaceutical agents.
\end{abstract}

Keywords: Albizia bernieri, antimicrobial activity, disc diffusion method, microdilution method, minimum bactericidal concentration, minimum inhibitory concentration.

\section{Introduction}

Microbial strains developing stronger resistance to various antibiotics are growing in numbers which constitutes a significant public health problem. There is an urgent need to find new disposable and affordable remedies to face this problem [1]. A systematic screening of plant extracts as a source of anti-bacterial compounds has been undertaken in different laboratories [2,3].

Several Albizia species organ extracts from different countries had been reported displaying antimicrobial properties. They include the extracts of A. zygia leaf [4], A. julibrissin leaf, stem and flower [5], A. amara leaf, flower, pod and bark [6], A. lebbeck seed [7], A. anthelmintica root bark [8], A. amara and A. saman leaves [9], wood [10], A. andianthifolia bark and root [11]. Seed extracts from some endemic Albizia of Madagascar also exhibited antimicrobial effects [12]. The purpose of this study was to assess the antimicrobial properties of A. bernieri seeds, one of the 24 Albizia species endemic to Madagascar [13]. The effects of seed extracts were tested on pathogen germs responsible for serious infections in humans and many of which are resistant to antibiotics.

\subsection{Plant Materials}

\section{Materials And Methods}

A. bernieri is a large shrub or tree up to $25 \mathrm{~m}$ tall (Fig.1) growing throughout the western Part of Madagascar, from the North to the South. The plant was identified by comparison of voucher specimens, registered under 29133-SF, with herbarium samples of Department of Forest Research and Fish Farms of FOFIFA Antananarivo. Dry fruits were collected on July 2010 from Mampikony in the North West of Madagascar. 

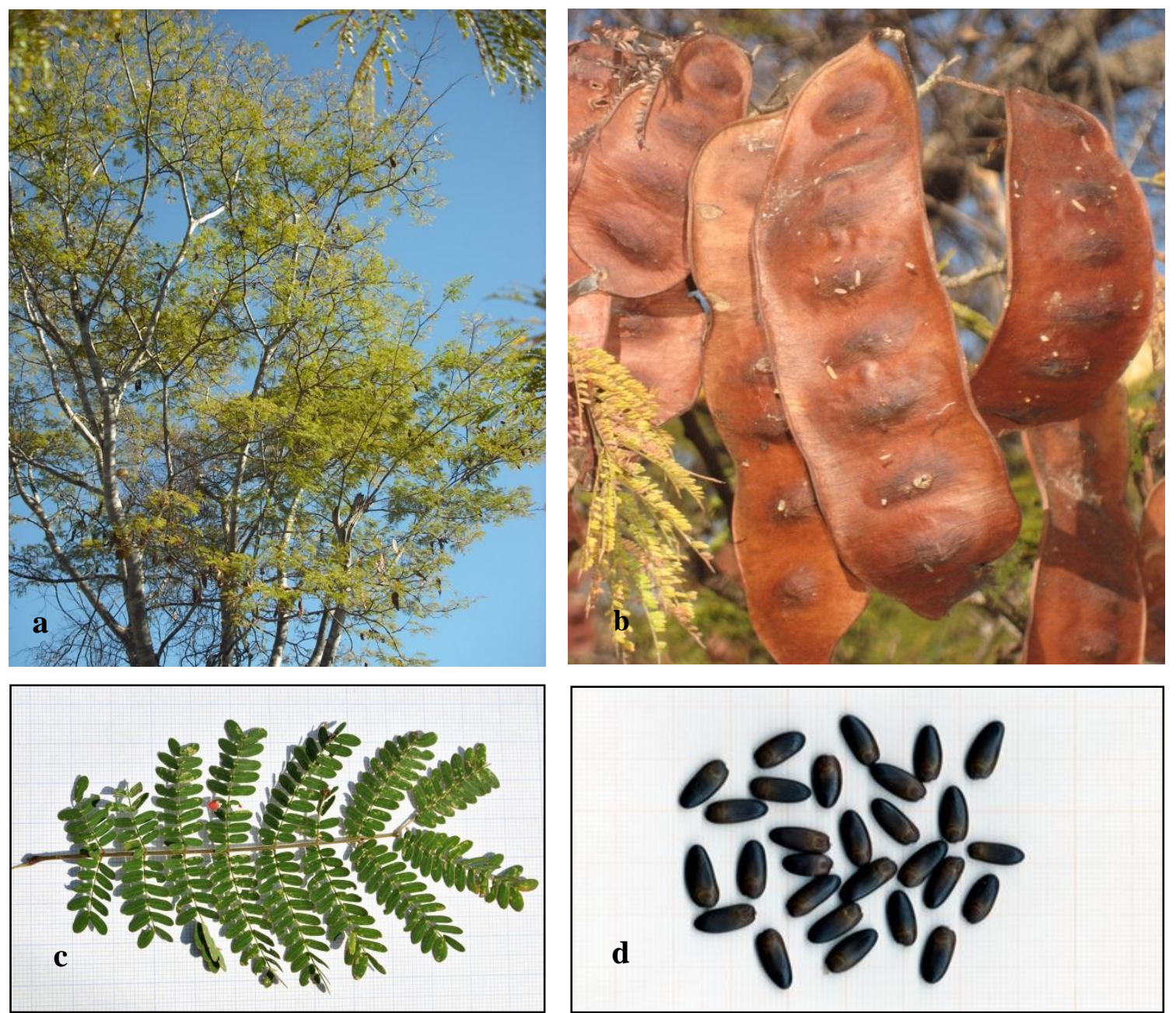

Source: the authors

Figure 1: Albizia bernieri: a) the whole plant; b) fruits; c) leaves; d) seeds

\subsection{Microorganism Strains}

The 10 microorganisms used in this study consisted of 4 Gram (-) bacteria, 5 Gram (+) bacteria and 1 yeast (TABLE 1). They were maintained on agar slant at $4^{\circ} \mathrm{C}$ and cultured on a fresh appropriate agar plate $24 \mathrm{~h}$ prior to any antimicrobial test.

TABLE 1: List of germs used

\begin{tabular}{|l|l|c|}
\hline \multicolumn{1}{|c|}{ Strains } & \multicolumn{1}{c|}{ Reference } & Gram \\
\hline Staphylococcus aureus & ATCC 25923 & + \\
\hline Bacillus cereus & ATCC 14579 & + \\
\hline Streptococcus pneumoniae & ATCC 6305 & + \\
\hline Streptococcus pyogenes & ATCC 19615 & + \\
\hline Enterobacter aerogenes & ATCC 13048 & - \\
\hline Enterobacter cloacae & ATCC 13047 & - \\
\hline Yersinia enterocolitica & ATCC 23715 & - \\
\hline Pseudomonas aeruginosa & ATCC 10145 & - \\
\hline Clostridium perfringens & ATCC 13124 & - \\
\hline Candida albicans & ATCC 10231 & \\
\hline
\end{tabular}

\subsection{Chemicals for Antimicrobial Assay} $500 \mu \mathrm{g} / \mathrm{disc}$.

Antibiotic and antifungal used as references in this study were Neomycin $30 \mu \mathrm{g} / \mathrm{disc}$ and Miconazole

\subsection{Preparation of Seed Extracts}

\subsubsection{Seed Methanolic Extract}

Ground seed powder $(250 \mathrm{~g})$ was delipidated with hexan $(3 \mathrm{X} 500 \mathrm{ml})$, then extracted with methanol (3 X $500 \mathrm{ml}$ ). After filtration using a Whatman filter paper, extract was evaporated to dryness under reduced pressure. The dry residue dissolved in sterile distilled water constituted seed methanol extract (SME). 


\subsubsection{Saponosides Extraction}

SME was mixed with an equal volume of n-butanol. Aqueous phase was yet two times treated with an equal volume of n-butanol. The three organic phases gathered and the aqueous phase were evaporated to dryness under reduced pressure. Seven grams $(7 \mathrm{~g})$ of the aqueous phase residue were dissolved in $100 \mathrm{ml}$ of methanol. The soluble fraction obtained was gradually added to $300 \mathrm{ml}$ of acetone-diethyl ether mixture (v/v) cooled in an ice bath. After a few minutes of maceration the precipitates formed were recovered by centrifugation (1000 rpm during 5 minutes at $+4^{\circ} \mathrm{C}$ ). The supernatant was collected and treated under the same previous conditions. This operation was repeated three times. All the precipitates were gathered and solvent was removed by evaporation. The resulting residue $(3.99 \mathrm{~g})$ constituted the polar total saponosides named Sap1. Three grams $(3 \mathrm{~g})$ of the organic phase residue were dissolved in $100 \mathrm{ml}$ of methanol. The resulting solution was also submitted to the same treatment by acetone-diethyl ether mixture (v/v). After evaporation, $2.1 \mathrm{~g}$ of less polar total saponosides (Sap2) were obtained.

\subsubsection{Alkaloids Extraction}

Two extraction methods were used.

Alkaloid Extraction under Basic Conditions

Four grams (4g) of SME powder were moistened with $20 \mathrm{ml}$ of ammoniac $20 \%$, then suspended in 300 $\mathrm{ml}$ of dichloromethane. The mixture was stirred at room temperature during $24 \mathrm{~h}$. After filtration, the solution was evaporated to dryness with a rotary evaporator at low pressure at $40^{\circ} \mathrm{C}$. The residue obtained was dissolved in $20 \mathrm{ml}$ of water and the solution was acidified with sulfuric acid (10\%) until $\mathrm{pH} 2-3$ and then extracted with ether to remove acidic and neutral lipophilic compounds. After adjusting its pH to $9-10$ with $\mathrm{NH}_{4} \mathrm{OH}(20 \%)$, the aqueous solution was extracted with dichloromethane $(3 \times 20 \mathrm{ml})$. The lower organic phase was washed three times with distilled water, then dehydrated with anhydrous sodium sulphate $\left(\mathrm{Na}_{2} \mathrm{SO} 4\right)$ and evaporated to dryness under reduced pressure. The residue obtained was the crude total alkaloid Alk1.

\section{Alkaloid Extraction under Acidic Conditions}

SME powder (4g), moistened with HCL 1M (30 ml ), was suspended in $100 \mathrm{ml}$ of methanol and stirred for $24 \mathrm{~h}$ at room temperature. After filtration, the solution was evaporated to dryness under reduced pressure. The aqueous acidic solution was alkalinized to $\mathrm{pH} 9-10$ with sodium hydroxide ( $\mathrm{NaOH} 20 \%$ ), then extracted with3 x $20 \mathrm{ml}$ of dichloromethane. The organic phase was dehydrated with anhydrous sodium sulphate $\left(\mathrm{Na}_{2} \mathrm{SO}_{4}\right)$ and evaporated to dryness under reduced pressure to yield the crude total alkaloid Alk2.

The five seed extracts tested are summarized in TABLE 2.

TABLE 2: List of seed extracts tested

\begin{tabular}{|c|l|}
\hline Abbreviations & \multicolumn{1}{|c|}{ Extracts } \\
\hline SME & Seed methanolic extract \\
\hline Sap1 & Total saponosides from aqueous butanol phase of SME \\
\hline Sap2 & Total saponosides from organic butanol phase of SME \\
\hline Alk1 & Total alkaloids under alkaline extraction \\
\hline Alk2 & Total alkaloids under acidic extraction \\
\hline
\end{tabular}

\subsection{Phytochemical Screening}

The reactions of chemical group detection were those developed by $[14,15]$.

\subsection{Antimicrobial Assays}

All the materials and methods used for antimicrobial assay were detailed in our previous paper [16]

\subsubsection{Antimicrobial Activity Test}

The in vitro antimicrobial activity of the extracts was determined using disc diffusion method of Pyun et al. [17] and Ngameni et al. [18]. The results were interpreted using the scale of Ponce et al. [19] and Celikel et al. [20]. Bacteria are not sensitive for an inhibition zone diameter (IZD) less than $8 \mathrm{~mm}$, sensitive for IZD of $9-14 \mathrm{~mm}$, very sensitive for IZD of $15-19 \mathrm{~mm}$ and extremely sensitive for IZD larger than $20 \mathrm{~mm}$.

Antifungal activity was evaluated by a method described by Favel et al. [21].

Negative controls were prepared by using the same solvents employed to dissolve the plant extract samples while the standard antibiotics were used as positive controls. All the experiments were performed in triplicate.

\subsubsection{MIC, MBC and MFC Determination}

Minimum Inhibitory Concentration (MIC), Minimum Bactericidal Concentration (MBC) and Minimum Fungicidal Concentration (MFC) were determined by microdilution method [22].

The standards used to interpret MIC results were those of Dalmarco et al. [2]. For crude extracts and fractions, a MIC lower than $100 \mu \mathrm{g} / \mathrm{mL}$ was considered as an excellent effect, from 100 to $500 \mu \mathrm{g} / \mathrm{ml}$ as 
moderate, from 500 to $1000 \mu \mathrm{g} / \mathrm{mL}$ as weak, and over $1000 \mu \mathrm{g} / \mathrm{ml}$ as inactive. The extract action is bactericidal or fungicidal whether its ratio $\mathrm{MBC} / \mathrm{MIC}$ or $\mathrm{MFC} / \mathrm{MIC}$ is $\leq 4$ ) and bacteriostatic and fungistatic when the ratio is $>4[23,24,25]$.

\subsection{Extraction yields}

\section{Results}

Extraction yields are shown in TABLE 3. They were calculated by reference to the starting material, i.e. seed powder for SME and SME for Sap1, Sap2, Alk1 and Alk2. Extraction yields ranged from 1.16\% (Alk1) to SME $(16.02 \%)$.

TABLE 3: Extraction yields of the different extracts

\begin{tabular}{|l|l|}
\hline Extract & Yield \\
\hline SME & $16.02 \%$ \\
\hline Sap1 & $9.97 \%$ \\
\hline Sap2 & $5.5 \%$ \\
\hline Alk1 & $1.16 \%$ \\
\hline Alk2 & $2.78 \%$ \\
\hline
\end{tabular}

\subsection{Phytochemical analysis}

The major secondary metabolites identified in SME extracts can be seen in TABLE 4. Alkaloids, saponosides, tannins, polyphenols, steroids, triterpenes and cardenolids were present, while flavonoids, leucoanthocyanins, coumarins, iridoïds, steroids, unsaturated sterols and quinones were not detected. Sap1 and Sap2 were contaminated with alkaloid traces, whereas Alk1 and Alk2 were free from any contamination.

TABLE 4: Phytochemical screening of A. bernieri seed extracts

\begin{tabular}{|l|l|c|c|c|c|c|}
\hline \multicolumn{1}{|c|}{ Chemical groups } & \multicolumn{1}{|c|}{ Tests } & SME & Sap1 & Sap2 & Alk1 & Alk2 \\
\hline \multirow{4}{*}{ Alkaloids } & Mayer & + & \pm & \pm & +++ & +++ \\
\cline { 2 - 7 } & Wagner & + & \pm & \pm & +++ & +++ \\
\cline { 2 - 7 } & Dragendorff & + & \pm & \pm & +++ & +++ \\
\hline & Foam test & + & & & & \\
\cline { 2 - 7 } & Hemolytic test & + & +++ & +++ & - & - \\
\hline Flavonoids & Willstätter & - & - & - & - & - \\
\hline Leucoanthocyanins & Bate-Smith & - & - & - & - & - \\
\hline Cardenolids & & + & - & - & - & - \\
\hline Cyanogenetic glycosides & Grignard & - & - & - & - & - \\
\hline Unsaturated lactones & Kedde & - & - & - & - & - \\
\hline Coumarins & & - & - & - & - & - \\
\hline Tannins and Polyphenols & Gelatin 1\% & + & - & - & - & - \\
\cline { 2 - 8 } & Gelatin-salt 10\% & - & - & - & - & - \\
\cline { 2 - 8 } & FeCl & & - & - \\
\hline
\end{tabular}

+: positive test; -: negative test

\subsection{Antimicrobial activity}

At the concentration of $1 \mathrm{mg} /$ disc, a concentration often used in antimicrobial activity assessment in plant extracts [26, 27, 28, 16], all the 5 extracts displayed antibacterial activity with IZD ranging from 8 to 27 mm (TABLE 5). However, activity depended on the extract and the microorganism used. 
Antimicrobial Activity of Seed Extracts from Albizia bernieri E. Fourn. (Fabaceae)

TABLE 5: Effects of A. bernieri seed extracts by disc diffusion method

\begin{tabular}{|c|c|c|c|c|c|c|c|c|}
\hline & \multirow{3}{*}{ Strains } & \multicolumn{7}{|c|}{ Inhibition zone diameter $(\mathrm{mm})$} \\
\hline & & \multicolumn{5}{|c|}{ Extracts $(1000 \mu \mathrm{g} / \mathrm{disc})$} & \multirow{2}{*}{$\begin{array}{l}\text { Neomycin } \\
30 \mu g / d i s c \\
\end{array}$} & \multirow{2}{*}{$\begin{array}{l}\text { Miconazole } \\
500 \mu \mathrm{g} / \mathrm{disc}\end{array}$} \\
\hline & & SME & Sap1 & Sap2 & Alk1 & Alk2 & & \\
\hline \multirow{4}{*}{ 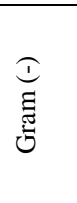 } & $\begin{array}{l}\text { Enterobacter cloacae } \\
\text { ATCC } 13047\end{array}$ & 20 & 18 & 22 & 26 & 25 & 27 & - \\
\hline & $\begin{array}{l}\text { Enterobacter aerogenes } \\
\text { ATCC } 13048\end{array}$ & 7 & 7 & 9 & 11.5 & 11 & 19 & - \\
\hline & Pseudomonas aeruginosa & 8 & 8 & 10 & 11 & 12 & 18 & - \\
\hline & Yersinia enterocolitica & 7 & 6 & 10 & 13 & 11 & 20 & - \\
\hline \multirow{5}{*}{$\underset{\Xi}{\underset{\Xi}{\Xi}}$} & $\begin{array}{l}\text { Streptococcus } \\
\text { pneumoniae }\end{array}$ & 9 & 9 & 12 & 14 & 14 & 23 & - \\
\hline & Streptococcus pyogenes & 9 & 8 & 10 & 9 & 20 & 24 & - \\
\hline & Staphylococcus aureus & 9 & 9 & 10 & 10 & 14 & 18 & - \\
\hline & Clostridium perfringens & 9 & 9 & 10 & 13 & 11 & 22 & - \\
\hline & Bacillus cereus & 9 & 9 & 10 & 10 & 14 & 21 & - \\
\hline Yeast & Candida albicans & 6 & 6 & 6 & 12 & 10 & - & 25 \\
\hline
\end{tabular}

Alk1 and Alk2 were active against all the microorganisms tested and were the most efficient. Sap2 was active against bacteria but not against Candida albicans. SME and Sap1 were the less active (IZD $\leq 9 \mathrm{~mm}$ ) against all the strains tested except Enterobacter cloacae. Enterobacter aerogenes, Yersinia enterocolitica and Candida albicans were not sensitive to these 2 extracts.

Neomycin $30 \mu \mathrm{g}$ and miconazole $500 \mu \mathrm{g}$ were more effective than all the A. bernieri seed extracts. The antimicrobial activity of the 5 extracts assessed by microdilution method is shown in TABLE 6.

Regarding MIC values, 48\% were $<100 \mu \mathrm{g} / \mathrm{ml}, 20 \%$ between 100 and $500 \mu \mathrm{g} / \mathrm{ml}, 26 \%$ from 500 to $1000 \mu \mathrm{g} / \mathrm{ml}$ and $6 \%>1000 \mu \mathrm{g} / \mathrm{ml}$. The values ranged from 31.25 to $500 \mu \mathrm{g} / \mathrm{ml}, 62.5$ to $>1000 \mu \mathrm{g} / \mathrm{ml}, 15.6$ to $500 \mu \mathrm{g} / \mathrm{ml}, 3.9$ to $62.5 \mu \mathrm{g} / \mathrm{ml}$ and 1.95 to $15.6 \mu \mathrm{g} / \mathrm{ml}$ for SME, Sap1, Sap2, Alk1 and Alk2 respectively.

About the MBC or MFC values, 44\% were $<100 \mu \mathrm{g} / \mathrm{ml}, 18 \%$ between 100 and $500 \mu \mathrm{g} / \mathrm{ml}, 28 \%$ from 500 to $1000 \mu \mathrm{g} / \mathrm{ml}$ and $10 \%>1000 \mu \mathrm{g} / \mathrm{ml}$. These values were 125 to $>1000 \mu \mathrm{g} / \mathrm{ml}, 125$ to $>1000 \mu \mathrm{g} / \mathrm{ml}, 31.25$ to $1000 \mu \mathrm{g} / \mathrm{ml}, 7.8$ to $62.5 \mu \mathrm{g} / \mathrm{ml}, 3.9$ to $62.5 \mu \mathrm{g} / \mathrm{ml}$ for SME, Sap1, Sap2, Alk1 and Alk2 respectively. The ratios $\mathrm{MBC} / \mathrm{MCI}$ or MFC/MCI of all extracts varied from 1 to 4 which meant they had a bactericidal action against all the microorganisms tested.

\section{Discussion}

A. bernieri seeds, like those of all Albizia species from Madagascar so far studied, mainly contained saponosides and alkaloids. The n-butanol fractionation separated the A. bernieri saponosides into 2 chemical groups: polar saponosides which have affinity to aqueous phase (Sap1) and less polar saponosides found in organic phase (Sap2). Alkaloids were better extracted under acidic extraction as reported by George et al. [29].

Regardless the method used to assess the antimicrobial activity, all the A. bernieri seed extracts were efficient but their effects depended upon the germs tested. They generally displayed a broad spectrum activity.

Activity levels were generally higher in liquid than in solid medium. In fact, activity considered as nonexistent (IZD $<8 \mathrm{~mm}$ ) or moderate (IZD between 9 and $14 \mathrm{~mm}$ ) in solid medium were excellent $(\mathrm{MIC}<100 \mu \mathrm{g} / \mathrm{ml})$ in liquid medium. As examples, against Candida albicans Alk1 had IZD = $7 \mathrm{~mm}$ and MIC = $62.5 \mu \mathrm{g} / \mathrm{ml}$ and against Enterobacter aerogenes, Clostridium perfringens and Candida albicans Alk 2 had IZD = $10-11 \mathrm{~mm}$ and $\mathrm{MIC}=3.9-15.6 \mu \mathrm{g} / \mathrm{ml}$. Bioactive compounds probably diffused little or not at all in solid medium. SME contained different secondary metabolites such alkaloids, polyphenols, saponins and triterpenes known for their antimicrobial properties. SME was substantially less active than saponosides and alkaloids it contained. At least, that might be partially due to negative interactions between contaminants and the active compounds. With the two methods used the alkaloids were more active than saponosides against all the strains tested. Their MIC between 1.95 and $62.5 \mu \mathrm{g} / \mathrm{ml}$ and their MBC between 3.9 and $62.5 \mu \mathrm{g} / \mathrm{ml}$ allowed to rank them among extracts with excellent effects [2]. Their activity on Enterobacter cloacae and Streptococcus pyogenes, the most sensitive bacteria tested, was comparable with that of neomycine at $30 \mu \mathrm{g} / \mathrm{ml}$. It is realistic to expect that pure alkaloids could be at least as efficient as this standard antibiotic. Concerning the saponosides group, the less polar saponosides (Sap2) were more efficient that the polar saponosides (Sap1). As noted above, the standards used to interpret MIC results were those of Dalmarco et al. [2]. However, it should be noted that there is no consensus on the inhibition level for natural products [30]. Compared to antimicrobial effects of other Albizia species extracts from Madagascar, the A. bernieri extracts with MIC values between 1.5 and 1000 $\mu \mathrm{g} / \mathrm{ml}$, are by far more effective than the extracts of $A$. arenicola leaves on Candida albicans $(\mathrm{MIC}=15620$ $\mu \mathrm{g} / \mathrm{ml}$ ), the A. aurisparsa seeds on Bacillus cereus ( $\mathrm{MIC}=1980 \mu \mathrm{g} / \mathrm{ml}$ ), the $A$. divaricata seeds on Pseudomonas aeruginosa $(\mathrm{MIC}=3120 \mu \mathrm{g} / \mathrm{ml})$, the $A$. mahalao seeds $(\mathrm{MIC}=3750 \mu \mathrm{g} / \mathrm{ml})$ and the A. polyphylla seeds $(\mathrm{MIC}=2420 \mu \mathrm{g} / \mathrm{ml}$ ) on Staphylococcus aureus[31]. In comparison with several plant extracts considered 
as active by the authors, the $A$. bernieri seed extracts were more efficient. As illustrations, SME was by far more efficient than other plant crude extracts (TABLE 7). All the A. bernieri extracts were bactericidal and fungicidal against sensitive microorganisms at the concentrations tested. This property might be due to direct action of bioactive compounds on membrane resulting in its lysis and cell death. Further chemical study will allow knowing the number of active molecules and their originality compared with molecules from other Albizia species or other plants.

TABLE 6: MIC, MBC, MFC $(\mu \mathrm{g} / \mathrm{ml})$ and MBC/MIC or MFC/MIC A. bernieri seed extracts

\begin{tabular}{|c|c|c|c|c|c|}
\hline \multicolumn{2}{|r|}{ Strains } & \multirow{2}{*}{$\begin{array}{c}\text { Extract } \\
\text { SME } \\
\end{array}$} & \multirow{2}{*}{\begin{tabular}{|l} 
MIC \\
500
\end{tabular}} & \multirow{2}{*}{$\begin{array}{c}\text { MBC or MFC } \\
>1000\end{array}$} & \multirow{2}{*}{$\begin{array}{c}\begin{array}{c}\text { MBC/MIC or } \\
\text { MFC/MIC }\end{array} \\
\text { nd }\end{array}$} \\
\hline \multirow{20}{*}{ 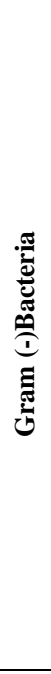 } & \multirow[t]{5}{*}{ Enterobacter cloacae } & & & & \\
\hline & & Sap1 & 1000 & 1000 & 1 \\
\hline & & Sap2 & 250 & 250 & 1 \\
\hline & & Alk1 & 31.25 & 31.25 & 1 \\
\hline & & Alk2 & 15.6 & 15.6 & 1 \\
\hline & \multirow[t]{5}{*}{ Enterobacter aerogenes } & SME & 500 & 1000 & 2 \\
\hline & & Sap1 & 1000 & $>1000$ & nd \\
\hline & & Sap2 & 250 & 500 & 2 \\
\hline & & Alk1 & 31.25 & 62.5 & 2 \\
\hline & & Alk2 & 15.6 & 62.5 & 4 \\
\hline & \multirow[t]{5}{*}{ Pseudomonas aeruginosa } & SME & 1000 & 1000 & 1 \\
\hline & & Sap1 & $>1000$ & nd & nd \\
\hline & & Sap2 & 500 & 1000 & 2 \\
\hline & & Alk1 & 62.5 & 62.5 & 1 \\
\hline & & Alk2 & 15.6 & 15.6 & 1 \\
\hline & \multirow[t]{5}{*}{ Yersinia enterocolitica } & SME & 500 & 500 & 1 \\
\hline & & Sap1 & 1000 & 1000 & 1 \\
\hline & & Sap2 & 250 & 250 & 1 \\
\hline & & Alk1 & 31.25 & 31.25 & 1 \\
\hline & & Alk2 & 15.6 & 15.6 & 1 \\
\hline \multirow{25}{*}{ 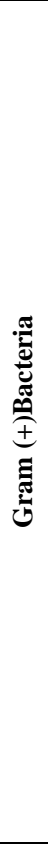 } & \multirow[t]{5}{*}{ Streptococcus pneumoniae } & SME & 31.25 & 125 & 4 \\
\hline & & Sap1 & 62.5 & 125 & 2 \\
\hline & & Sap2 & 15.6 & 31.25 & 2 \\
\hline & & Alk1 & 7.8 & 31.25 & 4 \\
\hline & & Alk2 & 1.95 & 7.8 & 4 \\
\hline & \multirow[t]{5}{*}{ Streptococcus pyogenes } & SME & 125 & 125 & 1 \\
\hline & & Sap1 & 125 & 125 & 1 \\
\hline & & Sap2 & 31.25 & 62.5 & 2 \\
\hline & & Alk1 & 3.9 & 7.8 & 2 \\
\hline & & Alk2 & 1.95 & 3.9 & 2 \\
\hline & \multirow[t]{5}{*}{ Staphylococcus aureus } & SME & 250 & 500 & 2 \\
\hline & & Sap1 & 1000 & 1000 & 1 \\
\hline & & Sap2 & 250 & 250 & 1 \\
\hline & & Alk1 & 31.25 & 31.25 & 1 \\
\hline & & Alk2 & 15.6 & 15.6 & 1 \\
\hline & \multirow[t]{5}{*}{ Clostridium perfringens } & SME & 125 & 250 & 2 \\
\hline & & Sap1 & $>1000$ & 1000 & nd \\
\hline & & Sap2 & 125 & 125 & 1 \\
\hline & & Alk1 & 15.6 & 31.25 & 2 \\
\hline & & Alk2 & 3.9 & 7.8 & 2 \\
\hline & \multirow[t]{5}{*}{ Bacillus cereus } & SME & 500 & 500 & 1 \\
\hline & & Sap1 & $>1000$ & $>1000$ & nd \\
\hline & & Sap2 & 500 & 500 & 1 \\
\hline & & Alk1 & 31.25 & 31.25 & 1 \\
\hline & & Alk2 & 15.6 & 15.6 & 1 \\
\hline \multirow{5}{*}{$\begin{array}{l}\overrightarrow{\mathrm{g}} \\
\vec{J}\end{array}$} & \multirow[t]{5}{*}{ Candida albicans } & SME & 500 & 1000 & 2 \\
\hline & & Sap1 & 1000 & $>1000$ & nd \\
\hline & & Sap2 & 125 & 500 & 4 \\
\hline & & Alk1 & 31.25 & 31.25 & 1 \\
\hline & & Alk2 & 7.8 & 7.8 & 1 \\
\hline
\end{tabular}

nd: not determined 
TABLE 7: Comparison of the MIC values of SME with those of other plant crude extracts on some germs

\begin{tabular}{|l|l|c|c|}
\hline \multicolumn{1}{|c|}{ Extracts } & \multicolumn{1}{|c|}{ Germ } & $\begin{array}{c}\text { MIC } \\
(\mu \mathrm{g} / \mathrm{ml})\end{array}$ & $\begin{array}{c}\text { MIC of SME } \\
(\mu \mathrm{g} / \mathrm{ml})\end{array}$ \\
\hline $\begin{array}{l}\text { aqueous trunk extract of Harungana } \\
\text { madagascariensis [32] }\end{array}$ & Pseudomonas aeruginosa & 6250 & 1000 \\
\hline hexanic leaf extract of Crotalaria retusa [33] & Bacillus cereus & 1250 & 500 \\
\hline aqueous crude extract of Allium sativum [34] & Streptococcus pneumoniae & 75000 & 31.25 \\
\hline methanolic leaf extract of Myrtusnivellei [35] & Candida albicans & 4500 & 500 \\
\hline
\end{tabular}

\section{Conclusion}

The A. bernieri seeds contain interesting antimicrobial agents from various chemical groups but alkaloids displayed the best activity. Alkaloids are a group of major therapeutic interest in terms of number, structural diversity and range of pharmacological properties. A. bernieri seed extracts could be used to treat gastrointestinal infections and skin diseases caused by the germs tested. For example, they could be recommended to treat boils, wounds and injuries caused by or infected with Pseudomonas aeruginosa [36]. Further phytochemical research is needed to identify the active principles and to investigate other properties.

\section{Acknowledgment}

The authors are grateful to the Centre National d'Application deRecherchesPharmaceutiques (CNARP) for its helpful support to this work.

\section{References}

[1]. C. Zongo, A. Savadogo, M.K. Somda, J. Koudou and A.S. Traore, In vitro evaluation of the antimicrobial and antioxidant properties of extracts from whole plant of Alternanthera pungens H.B. \& K. and leaves of Combretum sericeum G. Don. International Journal of Phytomedicine, 3, 2011, 182-191.

[2]. J.B. Dalmarco, E.M. Dalmarco, J. Koelzer, M.G. Pizzolatti and T.S. Fröde. Isolation and identification of bioactive compounds responsible for the anti-bacterial efficacy of Lotus corniculatus var. São Gabriel, International Journal of Green Pharmacy, 4, 2010, 108-114.

[3]. O. Stefanovic and L. Comic, Inhibitory effect of Cytisus nigricans L. and Cytisus capitatus Scop. on growth of bacteria, African Journal of Microbiology Research, 5(27), 2011, 4725-4730.

[4]. O. Odeyemi, A.O. Oluduro and O.M. David, Evaluation of Antimicrobial Activities of Albizia zygia DC Leaf Extracts against Some Clinically Important Pathogens, Journal of Natural Sciences Research, 4(19), 2014, 98-105.

[5]. P.V. Rajalakhmi and K. Senthil, Flavonoid content and antibacterial activity of Albizia julibrissin Durazz. Leaf, stem and flower extracts against clinically isolated bacterial pathogens, International Journal of Pharmaceutical Sciences, 6(11,) 2014, 506-508.

[6]. G. Shuba, B. Govindaraju, N.D. Satyanarayan and K.S. Manjunatha, Antibacterial activity of different solvent extracts of Albizia amara, Manjun Indian J.Sci.Res. 5(2), 2014, 9-12.

[7]. S.K. Sirohi, N. Goel and N. Singh, Influence of Albizia lebbeck saponin and Its Fractions on in vitro gas production kinetics, rumen methanogenesis, and rumen fermentation characteristics, ISRN Veterinary Science, 2014, 2014, p10.

[8]. K.B.D. Runyoro, C.C. Joseph, O.D. Ngassapa, M.P. Darokar, S.K. Srivastava, M.I.N. Matee and C.W. Wright, Anticandida Agents from a Tanzanian Plant Albizia anthelmintica, J. Chin. Chem. Soc. 62, 2015, 669-674.

[9]. H.N. Venkatesh, S. Thippeswamy, R.U. Abhishek and D.C. Mohana, Antibacterial activity of alkaloid extracts and active constituents of some selected plants against Xanthomonas campestris, Journal of Agricultural Technology11(3), $2015,683-691$.

[10]. N. Joycharat, C. Boonma, S. Thammavong, B. Yingyongnarongkul, S. Limsuwan and S.P. Voravuthikunchai, Chemical constituents and biological activities of Albizia myriophylla wood, Pharmaceutical Biology, 2015, 1-12.

[11]. C.F. Tchinda, I.K. Voukeng, V.P. Beng and V. Kuete, Antibacterial activities of the methanol extracts of Albizia adianthifolia, Alchornea laxiflora, Laportea ovalifolia and three other Cameroonian plants against multi-drug resistant Gram-negative bacteria, Saudi Journal of Biological Sciences, 24, 2017, 950-955,

[12]. D.A.D. Rakoto, R. Randrianarivo, M. El-Yachouroutui, A.A. Arisoa, N. Raharisoa, N. Rakotondrasoa, P. Raoniharisoa and V. Jeannoda, Effects of Extracts from Albizia (Fabaceae) Endemic Species of Madagascar on Vegetable Seedling Development, Journal of Chemistry and Chemical Engineering, 6(4), 2012, 313-322.

[13]. D.J. Dupuy, J.N. Labat, R. Rabevohitra, J.F. Villiers, J. Bosser and J. Morat, The Leguminosae of Madagascar (Royal Botanic Gardens, Kew, Richmond, United Kingdom, 2002).

[14]. E.H.S. Fong, M. Tin-Wa, N.R. Farnsworth and R.H. Dobberstein, Phytochemical screening methods, Rev. Department of pharmacognosy and pharmacology, College of pharmacy, University of Illinois, 1977.

[15]. G.B. Marini-Bettolo, S. Nicoletti and M. Patami, Plant screening by chemical and chromatographic procedure under field conditions, Journal of Chromatography, 218, 1981, 113-217.

[16]. H.L. Andriamampianina, D.A.D. Rakoto, T. Petit, H. Ramanankierana, H.R. Randrianarivo and V.L. Jeannoda, Antimicrobial Activity of Extracts from Crotalaria bernieri Baill (Fabaceae), African Journal of Microbiology Research, 10(31), 2016, 12291239.

[17]. M.S. Pyun and S. Shin, Antifungal effects of the volatile oils from allium plants against trichophyton species and synergism of the oils with ketoconazole, Phytomedicine, 13(6), 2006, 394-400.

[18]. B. Ngameni, V. Kuete, I.K. Simo, A.T. Mbaveng, P.K. Awoussong, R.R. Patnam, B.T. Ngadjui, Antibacterial and antifungal activities of the crude extract and compounds from Dorstenia Turbinate (Moraceae), South African Journal of Botany, 75, 2009, 256-261.

[19]. A.G. Ponce, R. Fritz, C. del Valle and S.I Roura, Antimicrobial activity of essential oils on the native microflora of organic Swiss chard, Lebensmittel-Wissenschaft und -Technologie-LWT, 36, 2003, 679-684.

[20]. N. Celikel and G. Kavas, Antimicrobial properties of some essential oils against some pathogenic microorganisms, Czech Journal Food Science, 26(3), 2008, 174-181. 
[21]. A. Favel, M.D. Steinmetz, E.V. Regli, R. Olivier and G. Balandsard, In vitro antifungal activity of triterpenoid saponins, Planta Medica Journal, 60, 1994, 50-53

[22]. V. Kuete, D.C. Fozing, W.F.G.D. Kapche, A. T. Mbaveng, J.R. Kuiate, B.T. Ngadjui and Z.B. M Abega, Antimicrobial activity of the methanolic extract and compounds from Morus mesozygia stem bark, Journal ethnopharmacology, 124(3), 2009, $551-555$.

[23]. D.E. Djeussi, J.A.K. Noumedem, J. Seukep, A.G. Fankam, I.K. Voukeng, S.B. Tankeo, A.H.L. Nkuete and V. Kuete, Antibacterial activities of selected edible plants extracts against multidrug-resistant Gram (-) bacteria, Complementary and Alternative Medicine, 13(164), 2013 1-8.

[24]. H. Bouharb, K. El Badaoui, Zair T., J. El amri, Chakir S. and T. Alaoui. Sélection de quelques plantes médicinales du Zerhoun (Maroc central) pour l'activité antibactérienne contre Pseudomonas aeruginosa, Journal of Applied Biosciences, 78, 2014, 66856693.

[25]. G. Chamandi, Z. Olama and H. Holail. Antimicrobial effect of Propolis from different geographic origins in Lebanon, International Journal of Current Microbiology and Applied Sciences, 4(4), 2015, 328-342.

[26]. K. Sandeep, B. Shrivastava, and R.K Khajuria, Antimicrobial activity of Crotalaria burhia Buch.-Ham. Root, Indian Journal of Natural Products and Resources, 1(4), 2010, 481484.

[27]. M. Govindappa, N. Bharath, H.B. Shruthi, T.S. Sadananda and P. Sharanappa, Antimicrobial, antioxidant and in vitro antiinflammatory activity and phytochemical screening of Crotalaria pallida Aiton, African Journal of Pharmacy and Pharmacology, 5(21), 2011, 2359-2371.

[28]. W. Linthoingambi and S.S. Mutum, Antimicroial activities of different solvent extracts of Tithonia diversifolia (Hemsely) A. Gray, Asian Journal of Plant Science and Research, 3(5), 2013, 50-54.

[29]. G. Francis, Z. Kerem, P.S.H. Makkar and K. Becker, The biological action of saponins in animal systems: a review, British Journal of Nutrition, 88, 2002, 587-605.

[30]. I. A.M. Benko and S. Crovella, Ethnobotanical bioprospection of candidates for potential antimicrobial drugs from brazilian plants, Current Protein and Peptide Science, 11(3), 2010, 189-194.

[31]. L. Randriamampianina, A. Offroy, L. Mambu, R. Randrianarivo, D. Rakoto, V. Jeannoda, C. Djediat, S. Puiseux Dao and M. Edery, Marked toxicity of Albizia bernieri extracts on embryo-larval development in the medaka fish (Oryzias latipes), Toxicon, 64, 2013, 29-35

[32]. R. C. da Cruz, L.B. Denardi, N.J. Mossmann, M. Piana, S.H. Alves and M.M.A. de Campos Antimicrobial Activity and Chromatographic Analysis of Extracts from Tropaeolum pentaphyllum Lam. Tubers. Molecules, 21(566), 2016 1-11.

[33]. S.M. Maregesi, L. Pieters, O.D. Ngassapa, S. Apers, R. Vingerhoets, P. Cos, B.D.A. Vanden and J.V. Arnold, Screening of some Tanzanian medicinal plants from Bunda district for antibacterial, antifungal and antiviral activities, Journal of Ethnopharmacology, $119,2008,58-66$

[34]. EL-M.M. Abubakar, Efficacy of crude extracts of garlic (Allium sativum Linn.) against nosocomial Escherichia coli, Staphylococcus aureus, Streptococcus pneumoniea and Pseudomonas aeruginosa, Journal of Medicinal Plants Research, 3(4), 2009, 179-185.

[35]. M. Touaibia and F.Z. Chaouch, Propriétés antioxydantes et antimicrobiennes des extraits de Myrtus nivellei Batt et Trab. obtenus in situ et in vitro, Phytothérapie, Lavoisier SAS, 2015, 1-7.

[36]. M.N Bobby, E.G. Wesely, M. Johnson, A in vitro anti-bacterial activity of leaves extracts of Albizia lebbeck Benth against some selected pathogens, Asian Pacific Journal of Tropical Biomedicine, 2012, 859-862. 